\title{
Frontal sinus mucopyelocele with orbital and intracranial extension
}

\author{
This article was published in the following Dove Press journal: \\ Eye and Brain \\ 29 May 2010 \\ Number of times this article has been viewed
}

\author{
Saroj Gupta' \\ Rashmi Goyal ${ }^{2}$ \\ Mradul Shahi ${ }^{3}$ \\ 'Department of Ophthalmology, \\ ${ }^{2}$ Department of Otolaryngology, \\ ${ }^{3}$ Neurosurgery Department, People's \\ Hospital, People's College of Medical \\ Science and Research Centre, Bhopal, \\ India
}

Correspondence: Saroj Gupta M-6,Windsor Estate Phase - II Chuna Bhatti, Kolar Road, Bhopal (MP)

India, Pin 462016

Tel +9l 07552420999

$\mathrm{Fax}+919926550364$

Email Sarojini94@yahoo.co.in

\begin{abstract}
This case report discusses a 52-year-old lady with nonaxial proptosis, diplopia and diminution of vision due to a mass lesion in the upper medial quadrant of the orbit. A computed tomography scan revealed a well-defined lesion in the frontal sinus area with orbital and intracranial extension. On exploring it was found to be a mucopyelocele of the frontal sinus. Surgical excision was done by an external approach. The symptoms and signs resolved completely within a week. Frontal sinus mucopyeloceles are benign and curable, and their early recognition and management is of paramount importance, because they can expand and cause orbital as well as intracranial complications.
\end{abstract}

Keywords: mucocele, mucopyelocele, paranasal sinuses, visual loss, proptosis

\section{Introduction}

Mucopyelocele is a chronic, expanding, mucosa-lined lesion of the paranasal sinus with retention of mucus and pus. Although benign, they have a tendency to expand by eroding the surrounding bony walls, and this displaces and destroys structures by causing pressure and bony resorption. ${ }^{1}$ Symptoms and signs of frontal mucopyelocele include pain, swelling, proptosis, diplopia, and loss of vision. Intracranial extension may lead to meningitis, meningoencephalitis, pneumocephalus, and brain abscess. The treatment is surgery by an external open approach.

\section{Case report}

A 52-year-old lady presented with a progressive bulging of the right eye with deterioration of vision in the previous three months. The globe was pushed forwards, downwards and outwards by a nontender diffuse, nonpulsatile mass in the upper medial quadrant of the orbit (Figure 1). On examination, vision in right eye was 20/200, whereas in left eye it was 20/20. Anterior rhinoscopic examination was normal. There was no history of headache, epistaxis, trauma, or seizures. Computed tomography of the orbit and sinuses revealed large a well-defined mass in the basifrontal area, which was isodense, nonenhancing, and measuring $3.6 \times 3.5 \times 2.4 \mathrm{~cm}$ with bony erosions. It extended into the anterior cranial fossa and was in direct contact with the meninges. It also eroded the superomedial wall of the right orbit and displaced the eyeball downwards and outwards. There was no significant enhancement of the lesion after contrast administration. No calcification was noted (Figure 2). Fine needle aspiration cytology was inconclusive. 


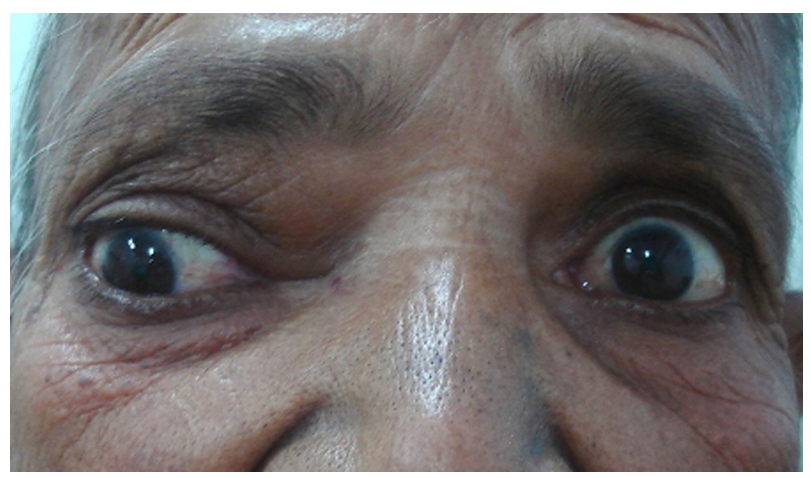

Figure I Clinical photograph of the patient showing proptosis with lateral displacement of the eyeball on the right side.

Based on clinical and radiologic findings, a provisional diagnosis of mucocele of the frontal sinus with orbital and intracranial extension was made. The differential diagnosis included dermoid cyst, histocytoma, fungal or tubercular infection, or a neoplastic lesion.

The patient was operated by a team consisting of a neurosurgeon, an ENT surgeon, and an ophthalmic surgeon. Incision was performed just below the medial half of the right eyebrow. On exploration it was found to be a mucopyelocele of the frontal sinus. Thick mucopurulent discharge was sucked out and mucocele was completely excised. The dura could be seen through the defect in the posterior wall of the frontal sinus and was found to be intact. In order

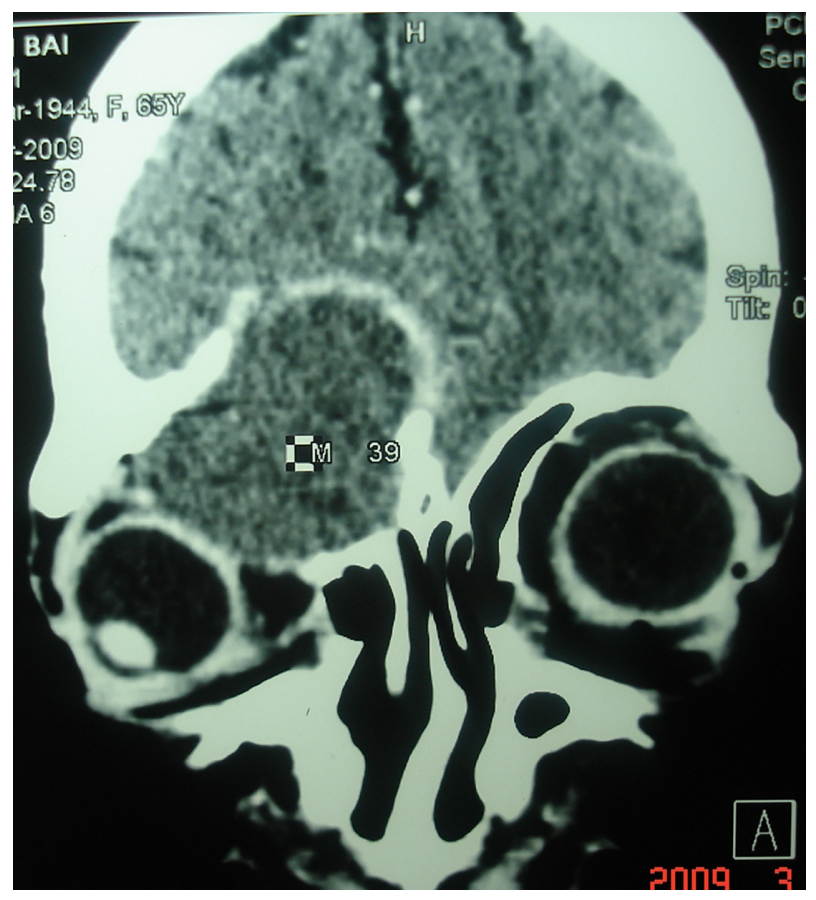

Figure 2 Computed tomography scan of the orbit showing a mass lesion on the right side, with extension into the orbit as well as into the cranial cavity, displacing the eyeball downwards and laterally.

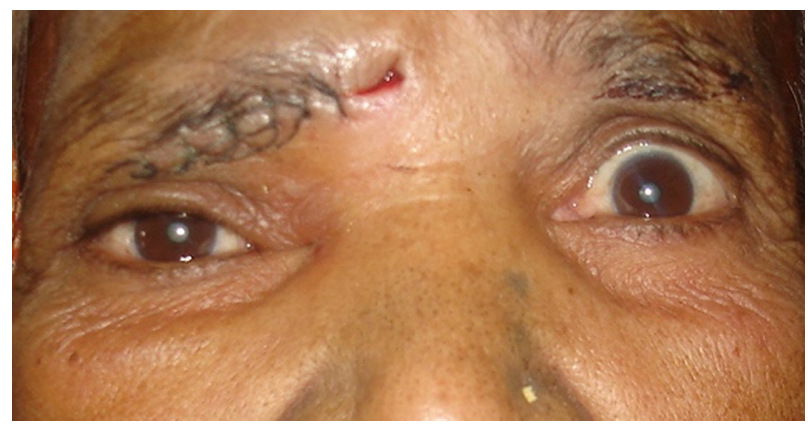

Figure 3 Resolution of proptosis after surgical treatment.

to prevent recurrence, the frontal sinus ostium was widened and a drainage tube was placed for six weeks. The skin flap was sutured. Postoperatively the patient was put on intravenous broad spectrum antibiotics (a ceftrioxone-salvactum combination) for 10 days. Proptosis and globe displacement resolved within a week (Figure 3). Vision also improved to $20 / 20$ in the right eye. She was discharged after two weeks. At six-month follow-up there was complete resolution of the proptosis and the patient was asymptomatic.

\section{Discussion}

Mucocele of the paranasal sinus is caused by obstruction of the sinus ostium. The closure of the ostium may be secondary to infection, allergy, trauma, or benign or malignant neoplasm. ${ }^{2}$ The reported incidence of mucocele of the sinuses causing unilateral proptosis has been variable, depending on the special interest of the investigators. Frontal sinus mucocele are the most common (65\%) among the paranasal sinus mucoceles. ${ }^{3}$ Mucoceles can be approached endoscopically or by an external Lynch-Howard approach. In the presence of significant complications and intracranial extension, a combined endoscopic and external approach may be necessary in the frontal region. Whatever approach is used, there is no necessity to reconstruct areas of bone resorption even when there is widespread dehiscence of the skull base. As long as the mucosal lining is intact, restitution of contours occur very rapidly. ${ }^{4}$ In this case, an external approach was used in order to gain better access to the area of lesion and to prevent blind curettage of any exposed dura mater.

There is a greater risk of optic neuropathy and visual loss with sphenoid sinus and Onodi cell mucoceles because of their proximity to the optic nerve. However, frontoethmoidal mucoceles are not benign and may compromise vision, especially if a posterior ethmoid sinus is involved, or if treatment is delayed and secondary infection has ensued to form a pyelocele. ${ }^{5}$ Therefore, management of paranasal mucoceles requires early diagnosis, prompt treatment, and multidisciplinary cooperation. 


\section{Disclosure}

The authors report no conflicts of interest in this work

\section{References}

1. Peral-Cagigal B, Barrientos-Lezcano J, Floriano-Blanco R, García-Cantera JM, Sánchez-Cuéllar LA, Verrier-Hernández A. Frontal sinus mucocele with intracranial and intraorbital extension. Med Oral Patol Oral Cir Bucal. 2006;11:E527-E530.
2. Rajan KV, Santhi T. Frontoethmoidal mucocele with orbital and intracranial extension. Ind J Otolaryngol Head Neck Surg. 2007;59(4):363-365.

3. Tan CSH, Yong VKY, Yip LW, Amrith S. An unusual presentation of a giant frontal sinus mucocele manifesting with a subcutaneous forehead mass. Ann Acad Med Singapore. 2005;34:397-398.

4. Lund VJ. Mucocoeles. In: Scott-Brown's Otolaryngology Head and Neck Surgery. 7th ed. London, UK: Hodder Arnold; 2008.

5. Loo JL, Looi AL, Seah LL. Visual outcomes in patients with paranasal mucoceles. Ophthal Plast Reconstr Surg. 2009;25(2):126-129.
Eye and Brain

\section{Publish your work in this journal}

Eye and Brain is an international, peer-reviewed, open access journal focusing on clinical and experimental research in the field of neuro-ophthalmology. All aspects of patient care are addressed within the journal as well as basic research. Papers covering original research, basic science, clinical and epidemiological studies, reviews and

\section{Dovepress}

evaluations, guidelines, expert opinion and commentary, case reports and extended reports are welcome. The manuscript management system is completely online and includes a very quick and fair peer-review system, which is all easy to use. Visit http://www.dovepress.com/ testimonials.php to read real quotes from published authors. 